\title{
Influence of seed treatment and packaging materials on seed longevity of cluster bean [Cyamopsistetra gonoloba(L.) Taub.]
}

\author{
Umesha $^{1^{*}}$, B. C. Channakeshava ${ }^{2}$, K. Bhanuprakash ${ }^{3}$, D. Nuthan ${ }^{4}$, R. Siddaraju ${ }^{1}$ and J. Lakshmi ${ }^{1}$ \\ ${ }^{1}$ All India Coordinated Research Project- National Seed Project (Crops), University of Agricultural Sciences, \\ Gandhi Krishi Vignan Kendra, Bengaluru-560065 (Karnataka), INDIA \\ ${ }^{2}$ Department of Seed Science and Technology, University of Agricultural Sciences, Gandhi Krishi Vignan Kendra, \\ Bengaluru-560065 (Karnataka), INDIA \\ ${ }^{3}$ Section of Seed Science and Technology, Indian Institution of Horticultural Research, Hesaraghatta, Bengaluru- \\ 560065 (Karnataka), INDIA \\ ${ }^{4}$ Associate Director of Research, University of Agricultural Sciences, Gandhi Krishi Vignan Kendra, Bengaluru- \\ 560065 (Karnataka), INDIA \\ *Corresponding author. E-mail: umesh3980@gmail.com
}

Received: June 12, 2016; Revised received: December 15, 2016; Accepted: February 15, 2017

\begin{abstract}
An experiment was conducted to investigate the influence of packaging materials and seed treatments on storability of cluster bean under ambient conditions of Bengaluru. The experiment consisted of six treatments viz. control $\left(T_{1}\right)$, bavistin @ $2 \mathrm{~g} \mathrm{~kg}^{-1}\left(\mathrm{~T}_{2}\right)$, spinosad @ $0.04 \mathrm{ml} / \mathrm{kg}\left(\mathrm{T}_{3}\right)$, neem leaf powder @ 1:20 ratio $\left(\mathrm{T}_{4}\right)$, Acorus calamus@10 g kg-1 $\left(T_{5}\right)$ and cow dung powder @ $10 \mathrm{~g} \mathrm{~kg}^{-1}\left(\mathrm{~T}_{6}\right)$ and three packaging materials viz., cloth bag $\left(\mathrm{C}_{1}\right)$ super grain bag $\left(C_{2}\right)$ and poly lined cloth bag $\left(C_{3}\right)$. Treated seed samples were stored in three containers under ambient storage conditions up to the duration of which seeds maintain minimum seed certification standards and samples were drawn at bimonthly intervals for ascertaining the seed quality parameters. The study suggested that seed treatment could be useful to prolong the storage life of cluster bean seeds. The seeds treated with spinosad $(0.04 \mathrm{ml} / \mathrm{kg})$ and stored in super-grain bag were better for maintenance of higher seed quality parameters [germination (80.00\%), root length $(11.70 \mathrm{~cm})$, shoot length $(13.60 \mathrm{~cm})$, mean seedling dry weight $(152 \mathrm{mg})$, seedling vigour index I and II (2024\&12140) and TDH activity (1.224) with low electrical conductivity $\left(0.368 \mathrm{dSm}^{-1}\right)$ ] up to 18 months under ambient conditions of Bengaluru (room temperature). Super-grain bag proved to be better storage container with higher seed quality attributes viz., germination (72.38\%), seedling vigour index-I (1726), total dehydrogenase activity (1.201) and other seed quality parameters compared to cloth bag. The study suggested that use of appropriate packaging material and seed treatment could be useful to prolong the storage life of cluster bean seeds.
\end{abstract}

Keywords: Acaruscalamus, Cluster bean, Guar, Spinosad, Super-grain bag

\section{INTRODUCTION}

Cluster bean (Cyamopsis tetragonoloba (L.) Taub.) commonly known as guar, belonging to the family Leguminosae is an annual and self-pollinated kharif legume crop grown for feed, green fodder, vegetable, green manuring and gum extraction from seed. Being drought hardy, it is grown mainly under rainfed conditions in India, since ancient times. It is primarily grown for its tender green pods in arid and semi-arid regions of our country and is a good source of carbohydrates, protein, fiber and minerals like calcium, phosphorous and iron and contains appreciable amount of vitamin C (Aykroyd, 1963). The qualities of the crop like high adaptation towards erratic rainfall, multiple industrial uses, soil enrichment properties, low input requirement, etc. have made the guar one of the most significant crops for farmers in arid areas of India. Cluster bean seeds have a large endosperm that contains galactomannon gum, a substance which forms a gel in water and is known as guar gum having main commercial value. Guar gum and its derivatives are critical ingredients of various sectors like food, petroleum/gas exploration, explosives, pharmaceuticals, cosmetics, paper industry, textile, paints/ distempers, aerial firefighting etc. (NRAA, 2014)

Seed deterioration is loss of seed quality, viability and vigor due to effect of adverse environmental factors (Kapoor et al., 2010). It is an undesirable attribute of agriculture. Annual losses due to deterioration can be as much as $25 \%$ of the harvested crop. It is one of the basic reasons for low productivity (Shelar et al., 2008). The process has been described as cumulative, irreversible, degenerative and inexorable process (Kapoor et al., 2011). As the seed is hygroscopic in nature, its quality is being affected due to variations in the environmental conditions viz., relative humidity, temperature, moisture content, gaseous exchange, 

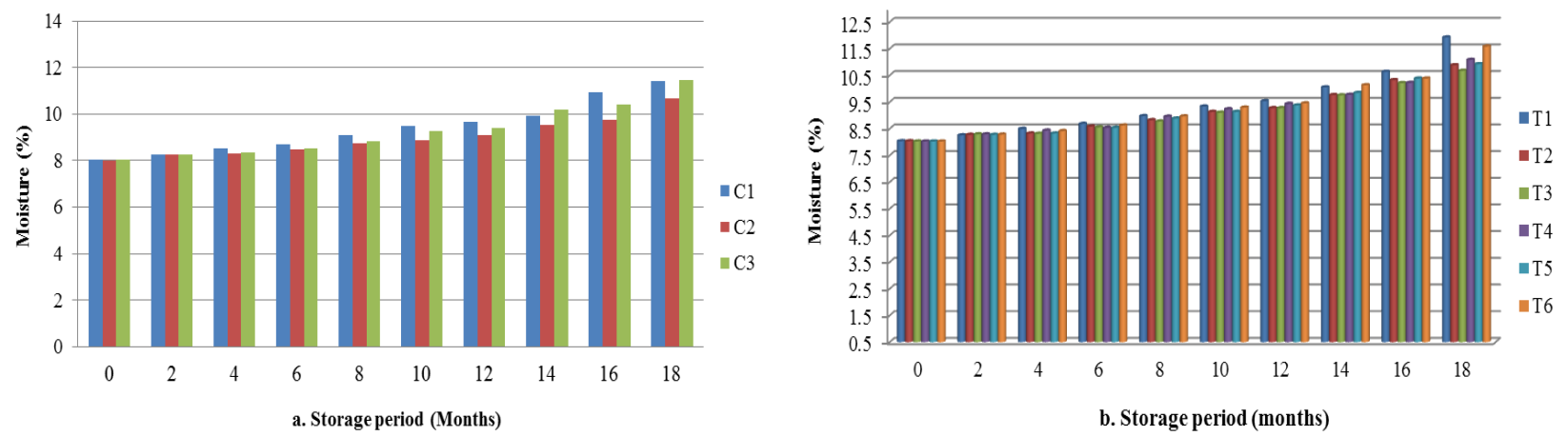

Fig. 1. Seed moisture content (\%) as influenced by containers (C) and seed treatment chemicals $(T)$ during storage of cluster bean var. Pusa navbahar (Containers: $C_{1}$ - Cloth bag/ Gunny bag; $C_{2}-$ Super grain bag $C_{3}-$ Polylined cloth bag,Seed treatments: $T_{1}-$ Control; $T_{2}-$ Bavistin $\left(2 \mathrm{~g} \mathrm{~kg}^{-1}\right) ; T_{3}-$ Spinosad $(0.04 \mathrm{ml} / \mathrm{kg}) ; T_{4}-$ Neem leaf powder (1:20 ratio); $T_{5}-$ Acorus calamus $(10 \mathrm{gm} / \mathrm{Kg}) ; T_{6}-$ Cow dung powder $\left(10 \mathrm{~g} \mathrm{~kg}^{-1}\right)$

packaging material etc. (Doijode, 1988). In order to prevent the quantitative and qualitative losses due to several biotic (bacteria, fungi, mites, insects and rodents) and abiotic factors during storage, several methods are being adopted such as seed treatment with suitable chemicals or plant products and storing the seeds in vapour proof containers like polythene bag, aluminium foils, tins or any sealed containers is found to be more useful in maintaining the desired quality of seeds for longer period. The seed storability is also considerably determined by the kind or variety of seeds. Some seeds are naturally short-lived, e.g., onion, soybeans, peanuts, etc., whereas some seeds like, tall fescue and annual rye grass, appear very similar but differ in storability. Genetic make-up of kind/ varieties also influences storability. Pulses are poor storers. These seeds lost their viability in a very short period of storage because of the high protein content. As other pulses, cluster bean seeds also lost their vig- our within one year of storage period. The germination percentage of seeds is reduced below the standard germination $(70 \%)$ within a year. The information on influence of seed treatment and storage containers on seed longevity of cluster bean seeds is meager. With this in view, a comprehensive study was envisaged to know the effect of seed treatment chemicals and packaging materials on storability of cluster bean.

\section{MATERIALS AND METHODS}

Freshly harvested seeds of cluster bean variety Pusa Navbahar were dried to safe moisture level (8\%) and treated separately with bavistin $(2 \mathrm{~g} / \mathrm{kg})$, spinosad $(0.04 \mathrm{ml} / \mathrm{kg})$, neem leaf powder (1:20 ratio), Acorus calamus $(10 \mathrm{~g} / \mathrm{Kg})$, cow dung powder $(10 \mathrm{~g} / \mathrm{kg})$. The untreated seeds were considered as control. The treated and untreated seeds were air dried under shade for 24 hours to bring back to its original moisture content and were packed in cloth bag, super grain bag and poly-

Table 1. Influence of containers (C) and seed treatment chemicals (T) on germination (\%) during storage of cluster bean var. Pusa navbahar.

\begin{tabular}{|c|c|c|c|c|c|c|c|c|c|c|}
\hline \multicolumn{11}{|c|}{ Storage period (months) } \\
\hline & Initial & 2 & 4 & 6 & 8 & 10 & 12 & 14 & 16 & 18 \\
\hline \multicolumn{11}{|l|}{ Containers (C) } \\
\hline $\mathrm{C}_{1}$ - Cloth bag & 94.75 & 91.63 & 89.75 & 87.71 & 84.79 & 80.96 & 79.38 & 74.42 & 68.79 & 62.00 \\
\hline $\mathrm{C}_{2}$ - Super grain bag & 94.71 & 93.58 & 91.54 & 90.21 & 86.88 & 82.42 & 81.67 & 79.38 & 75.79 & 72.38 \\
\hline $\mathrm{C}_{3}-$ Polylined cloth bag & 95.00 & 91.75 & 90.13 & 88.83 & 84.67 & 81.96 & 79.92 & 77.75 & 73.17 & 70.25 \\
\hline S.Em \pm & - & 0.41 & 0.19 & 0.18 & 0.16 & 0.19 & 0.14 & 0.19 & 0.16 & 0.15 \\
\hline $\mathrm{CD}$ at $5 \%$ & NS & 1.16 & 0.55 & 0.51 & 0.46 & 0.54 & 0.38 & 0.54 & 0.46 & 0.43 \\
\hline \multicolumn{11}{|l|}{ Seed treatment chemicals (T) } \\
\hline $\mathrm{T}_{1}-$ Control & 94.83 & 91.33 & 89.08 & 87.33 & 83.00 & 80.50 & 78.08 & 72.42 & 68.00 & 62.25 \\
\hline $\mathrm{T}_{2}-\operatorname{Bavistin}\left(2 \mathrm{~g} \mathrm{~kg}^{-1}\right)$ & 94.83 & 92.92 & 91.08 & 89.75 & 86.67 & 82.25 & 81.42 & 79.25 & 73.67 & 72.83 \\
\hline $\mathrm{T}_{3}-\operatorname{Spinosad}(0.04 \mathrm{ml} / \mathrm{kg})$ & 94.83 & 93.92 & 92.08 & 90.75 & 88.33 & 85.17 & 83.58 & 82.25 & 81.17 & 77.08 \\
\hline $\mathrm{T}_{4}-$ Neem leaf powder(1:20 ratio) & 94.75 & 92.00 & 90.25 & 89.00 & 84.67 & 81.33 & 79.25 & 76.58 & 70.83 & 65.50 \\
\hline $\mathrm{T}_{5}-$ Acoruscalamus $\left(10 \mathrm{~g} \mathrm{~kg}^{-1}\right)$ & 94.75 & 92.08 & 90.75 & 89.00 & 85.75 & 81.50 & 80.58 & 77.75 & 72.75 & 67.08 \\
\hline $\mathrm{T}_{6}-$ Cow dung powder $\left(10 \mathrm{~g} \mathrm{~kg}^{-1}\right)$ & 94.92 & 91.67 & 89.58 & 87.67 & 84.25 & 79.92 & 79.00 & 74.83 & 69.08 & 64.50 \\
\hline S.Em \pm & - & 0.58 & 0.27 & 0.25 & 0.23 & 0.27 & 0.19 & 0.27 & 0.22 & 0.21 \\
\hline $\mathrm{CD}$ at $5 \%$ & NS & 1.64 & 0.77 & 0.72 & 0.64 & 0.77 & 0.54 & 0.77 & 0.63 & 0.61 \\
\hline
\end{tabular}

NS - Non significant 
Umesha et al. / J. Appl. \& Nat. Sci. 9 (1): 482 - 491 (2017)
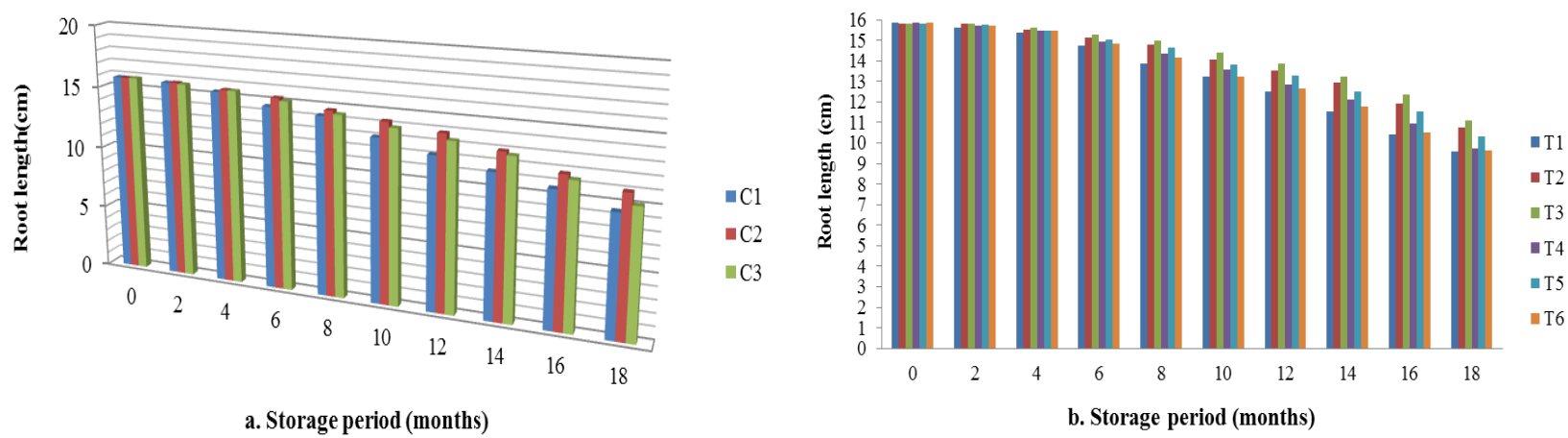

Fig. 2. Root length (cm) as influenced by containers (C) and seed treatment chemicals (T) during storage of cluster bean var. Pusa navbahar.
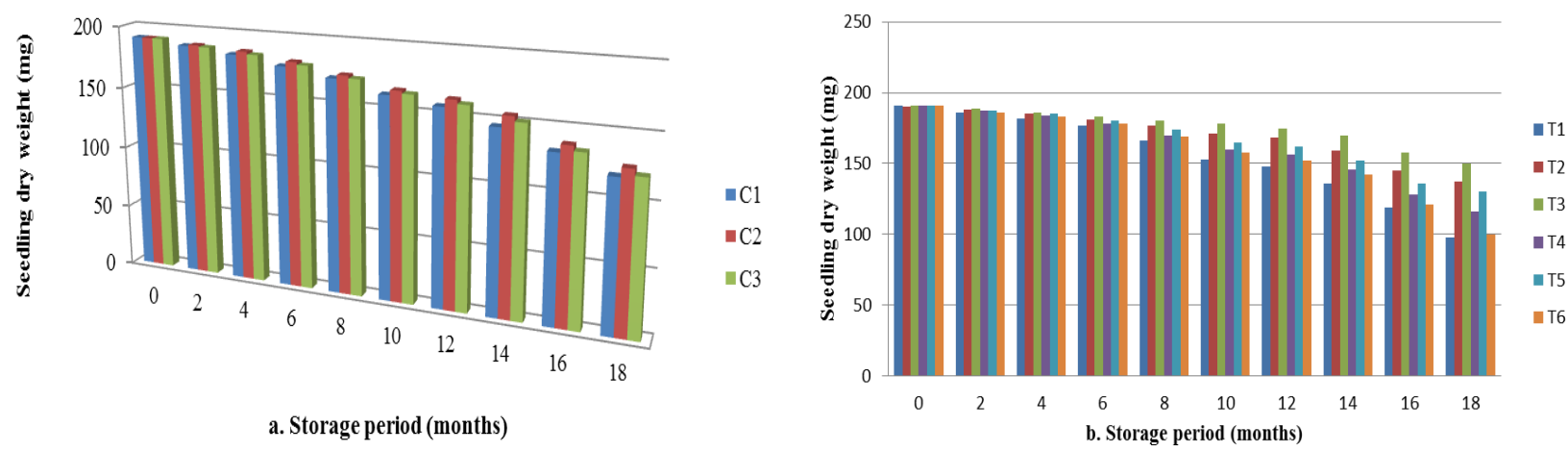

Fig. 3. Influence of containers $(C)$ and seed treatment chemicals $(T)$ on seedling dry weight (mg) during storage of cluster bean var. Pusa navbahar.

Table 1a. Influence of containers $(C)$ and seed treatment chemicals $(T)$ interaction $(C \times T)$ on germination per cent during storage of cluster bean var. Pusa navbahar.

\begin{tabular}{|c|c|c|c|c|c|c|c|c|c|c|}
\hline \multicolumn{11}{|c|}{ Storage period (months) } \\
\hline $\mathbf{C} \times \mathbf{T}$ & Initial & 2 & 4 & 6 & 8 & 10 & 12 & 14 & 16 & 18 \\
\hline $\mathrm{C}_{1} \mathrm{~T}_{1}$ & 94.75 & 91.00 & 88.25 & 85.50 & 81.50 & 78.25 & 75.75 & 70.25 & 64.00 & 54.50 \\
\hline $\mathrm{C}_{1} \mathrm{~T}_{2}$ & 94.75 & 92.00 & 90.00 & 89.00 & 85.75 & 81.50 & 81.00 & 76.00 & 69.50 & 69.50 \\
\hline $\mathrm{C}_{1} \mathrm{~T}_{3}$ & 94.75 & 93.00 & 91.00 & 89.75 & 88.00 & 85.50 & 82.75 & 81.25 & 79.50 & 73.25 \\
\hline $\mathrm{C}_{1} \mathrm{~T}_{4}$ & 94.75 & 91.00 & 90.00 & 88.00 & 85.00 & 81.00 & 78.50 & 73.00 & 66.50 & 58.25 \\
\hline $\mathrm{C}_{1} \mathrm{~T}_{5}$ & 94.75 & 92.00 & 90.00 & 87.50 & 84.50 & 80.25 & 80.25 & 74.25 & 68.50 & 59.50 \\
\hline $\mathrm{C}_{1} \mathrm{~T}_{6}$ & 94.75 & 90.75 & 89.25 & 86.50 & 84.00 & 79.25 & 78.00 & 71.75 & 64.75 & 57.00 \\
\hline $\mathrm{C}_{2} \mathrm{~T}_{1}$ & 94.75 & 92.25 & 90.00 & 89.25 & 84.50 & 83.00 & 80.50 & 76.00 & 71.50 & 68.00 \\
\hline $\mathrm{C}_{2} \mathrm{~T}_{2}$ & 94.75 & 94.25 & 92.25 & 90.75 & 88.25 & 82.75 & 82.50 & 81.50 & 77.50 & 75.50 \\
\hline $\mathrm{C}_{2} \mathrm{~T}_{3}$ & 94.75 & 94.50 & 93.25 & 91.75 & 90.00 & 85.00 & 84.25 & 83.25 & 81.50 & 80.00 \\
\hline $\mathrm{C}_{2} \mathrm{~T}_{4}$ & 94.50 & 93.75 & 90.75 & 90.25 & 85.50 & 81.25 & 80.75 & 79.25 & 74.50 & 69.50 \\
\hline $\mathrm{C}_{2} \mathrm{~T}_{5}$ & 94.50 & 92.75 & 92.25 & 90.25 & 87.25 & 82.25 & 81.50 & 79.75 & 77.25 & 72.00 \\
\hline $\mathrm{C}_{2} \mathrm{~T}_{6}$ & 95.00 & 93.25 & 90.75 & 89.00 & 85.75 & 80.25 & 80.50 & 76.50 & 72.50 & 69.25 \\
\hline $\mathrm{C}_{3} \mathrm{~T}_{1}$ & 95.00 & 90.75 & 89.00 & 87.25 & 83.00 & 80.25 & 78.00 & 71.00 & 68.50 & 64.25 \\
\hline $\mathrm{C}_{3} \mathrm{~T}_{2}$ & 95.00 & 92.50 & 91.00 & 89.50 & 86.00 & 82.50 & 80.75 & 80.25 & 74.00 & 73.50 \\
\hline $\mathrm{C}_{3} \mathrm{~T}_{3}$ & 95.00 & 93.50 & 92.00 & 90.75 & 87.00 & 85.00 & 83.75 & 82.25 & 82.50 & 78.00 \\
\hline $\mathrm{C}_{3} \mathrm{~T}_{4}$ & 95.00 & 91.25 & 90.00 & 88.75 & 83.50 & 81.75 & 78.50 & 77.50 & 71.50 & 68.75 \\
\hline $\mathrm{C}_{3} \mathrm{~T}_{5}$ & 95.00 & 91.50 & 90.00 & 89.25 & 85.50 & 82.00 & 80.00 & 79.25 & 72.50 & 69.75 \\
\hline $\mathrm{C}_{3} \mathrm{~T}_{6}$ & 95.00 & 91.00 & 88.75 & 87.50 & 83.00 & 80.25 & 78.50 & 76.25 & 70.00 & 67.25 \\
\hline S.Em \pm & - & - & - & - & 0.39 & 0.47 & 0.33 & 0.46 & 0.38 & 0.37 \\
\hline $\mathrm{CD}$ at $5 \%$ & NS & NS & NS & NS & 1.12 & 1.32 & 0.94 & 1.32 & 1.09 & 1.05 \\
\hline
\end{tabular}

NS - Non significant, Containers $\left(\mathbb{C} ; \mathrm{C}_{1}-\right.$ Cloth bag; $\mathrm{C}_{2}$ - Super grain bag; $\mathrm{C}_{3}$ - Polylined cloth bag; Seed Treatment chemicals (T); $\mathrm{T}_{1}-$ Control; $\mathrm{T}_{2}-$ Bavistin $\left(2 \mathrm{~g} \mathrm{~kg}^{-1}\right) ; \mathrm{T}_{3}-$ Spinosad $(0.04 \mathrm{ml} / \mathrm{kg}) ; \mathrm{T}_{4}-$ Neem leaf powder(1:20 ratio); $\mathrm{T}_{5}-$ Acorus calamus $\left(10 \mathrm{~g} \mathrm{~kg}^{-1}\right) ; \mathrm{T}_{6}-$ Cow dung powder $\left(10 \mathrm{~g} \mathrm{~kg}^{-1}\right)$ 
Umesha et al. / J. Appl. \& Nat. Sci. 9 (1): 482 - 491 (2017)
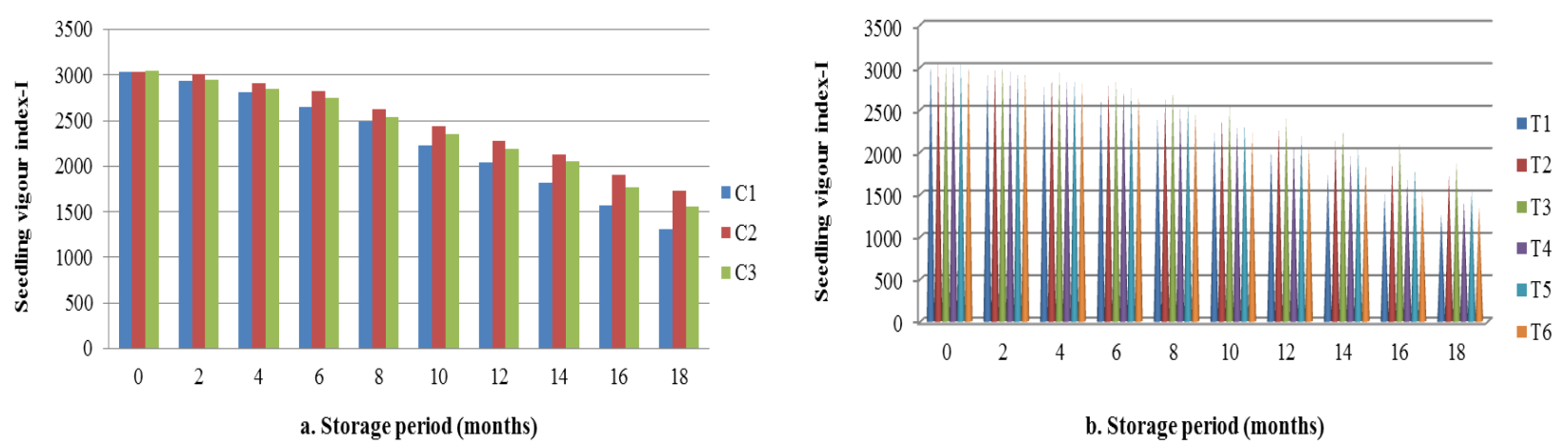

Fig. 4. Seedling vigour index-I as influenced by containers $(C)$ and seed treatment chemicals $(T)$ during storage of cluster bean var. Pusa navbahar.
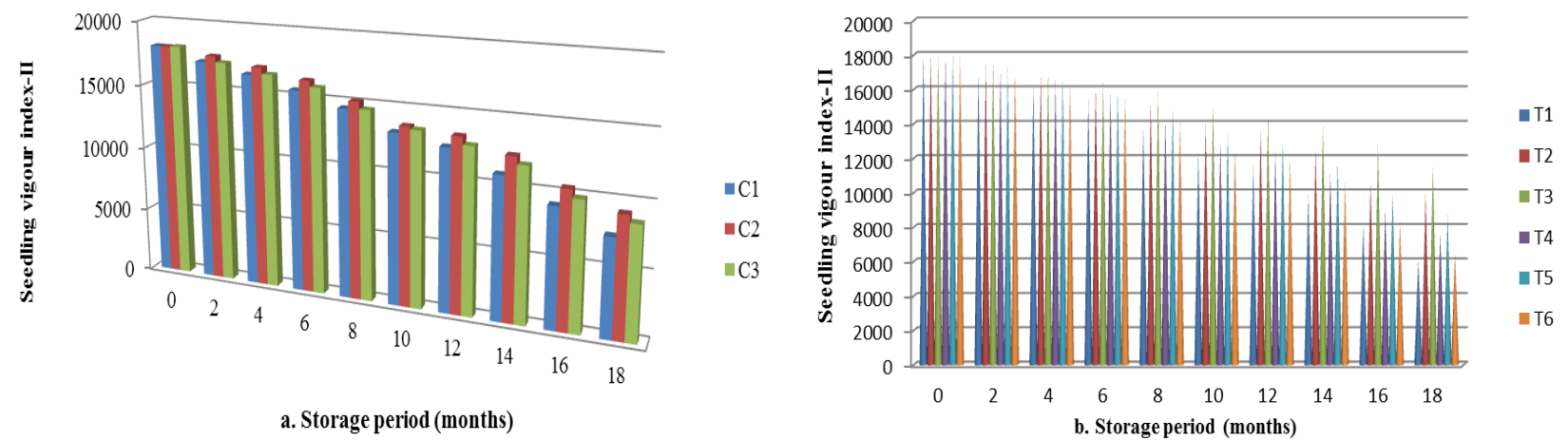

Fig. 5. Influence of containers $(C)$ and seed treatment chemicals $(T)$ on seedling vigour index-II during storage of cluster bean var. Pusa navbahar.

lined cloth bag and stored under ambient conditions of Bengaluru where minimum and maximum temperatures were $14.1^{\circ} \mathrm{C}$ to $21.2^{\circ} \mathrm{C}$ and $26.6^{\circ} \mathrm{C}$ to $34.7^{\circ} \mathrm{C}$, respectively and the mean relative humidity was 78 to 94.0 per cent during 18 months of storage (Anon., 2015). The seed samples were drawn at bimonthly intervals and estimated for seed quality attributes up to 18 months.

Moisture content was estimated by low constant tem- perature method as per the procedure outlined by ISTA Rules (Anon., 1996). Seeds were tested for germination by adopting 'between paper' method at $25 \pm 1^{\circ} \mathrm{C}$ (Anon., 1996). The germinated seedlings were evaluated on $14^{\text {th }}$ day of germination test. The total germination was expressed in percent on the basis of number of normal seedlings obtained. Ten normal seedlings were randomly selected in each replication from the germination test and root length was meas-

Table 2. Influence of containers $(\mathrm{C})$ and seed treatment chemicals $(\mathrm{T})$ on shoot length $(\mathrm{cm})$ during storage of cluster bean var. Pusa navbahar.

\begin{tabular}{|c|c|c|c|c|c|c|c|c|c|c|}
\hline \multicolumn{11}{|c|}{ Storage period (months) } \\
\hline & Initial & 2 & 4 & 6 & 8 & 10 & 12 & 14 & 16 & 18 \\
\hline \multicolumn{11}{|l|}{ Containers (C) } \\
\hline $\mathrm{C}_{1}-$ Cloth bag & 16.54 & 16.29 & 16.03 & 15.68 & 15.03 & 14.49 & 13.62 & 13.06 & 12.03 & 11.41 \\
\hline $\mathrm{C}_{2}$ - Super grain bag & 16.60 & 16.47 & 16.21 & 16.01 & 15.55 & 15.29 & 14.10 & 13.84 & 13.33 & 12.83 \\
\hline $\mathrm{C}_{3}-$ Polylined cloth bag & 16.57 & 16.43 & 16.13 & 15.80 & 15.49 & 14.82 & 13.96 & 13.61 & 12.60 & 11.91 \\
\hline S.Em \pm & - & - & 0.022 & 0.023 & 0.020 & 0.022 & 0.019 & 0.025 & 0.057 & 0.031 \\
\hline $\mathrm{CD}$ at $5 \%$ & NS & NS & 0.062 & 0.064 & 0.058 & 0.061 & 0.053 & 0.072 & 0.162 & 0.088 \\
\hline \multicolumn{11}{|l|}{ Seed treatment chemicals $(T)$} \\
\hline $\mathrm{T}_{1}-$ Control & 16.55 & 16.28 & 15.91 & 15.64 & 15.03 & 14.45 & 13.34 & 12.52 & 11.49 & 10.62 \\
\hline $\mathrm{T}_{2}-\operatorname{Bavistin}\left(2 \mathrm{~g} \mathrm{~kg}^{-1}\right)$ & 16.56 & 16.48 & 16.23 & 15.93 & 15.58 & 15.18 & 14.45 & 14.02 & 13.46 & 12.94 \\
\hline $\mathrm{T}_{3}-\operatorname{Spinosad}(0.04 \mathrm{ml} / \mathrm{kg})$ & 16.63 & 16.52 & 16.32 & 16.09 & 15.78 & 15.37 & 14.83 & 14.43 & 13.58 & 13.18 \\
\hline $\mathrm{T}_{4}-$ Neem leaf powder(1:20 ratio) & 16.53 & 16.34 & 16.11 & 15.79 & 15.23 & 14.70 & 13.48 & 13.26 & 12.56 & 11.86 \\
\hline $\mathrm{T}_{5}-$ Acoruscalamus $\left(10 \mathrm{~g} \mathrm{~kg}^{-1}\right)$ & 16.59 & 16.43 & 16.18 & 15.82 & 15.39 & 14.98 & 13.98 & 13.78 & 13.19 & 12.55 \\
\hline $\mathrm{T}_{6}-$ Cow dung powder $\left(10 \mathrm{~g} \mathrm{~kg}^{-1}\right)$ & 16.55 & 16.33 & 15.98 & 15.70 & 15.14 & 14.53 & 13.28 & 13.01 & 11.66 & 11.14 \\
\hline S.Em \pm & - & - & 0.031 & 0.032 & 0.029 & 0.031 & 0.026 & 0.036 & 0.081 & 0.044 \\
\hline $\mathrm{CD}$ at $5 \%$ & NS & NS & 0.087 & 0.090 & 0.082 & 0.087 & 0.075 & 0.102 & 0.229 & 0.124 \\
\hline
\end{tabular}

NS - Non significant 


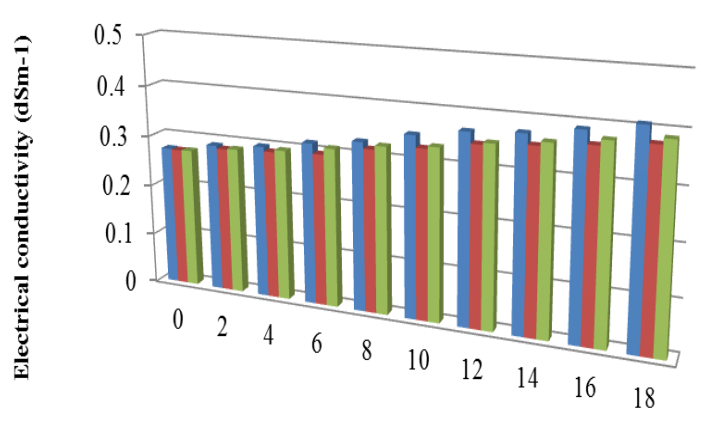

a. Storage period (months)
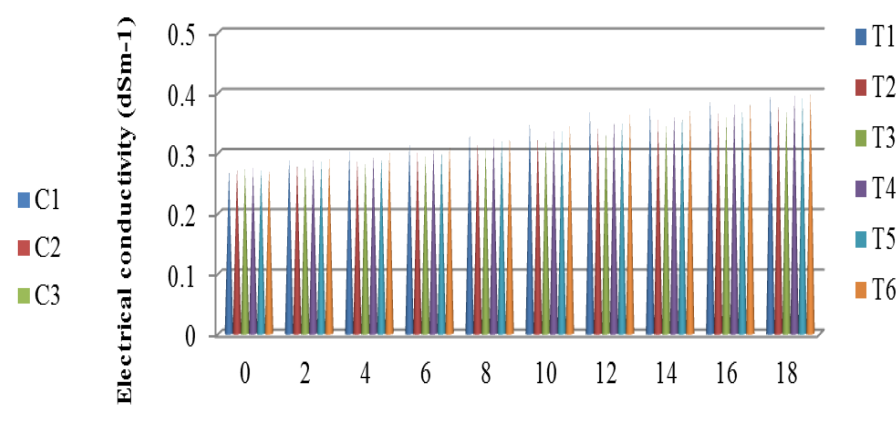

b. Storage period (months)

Fig. 6. Electrical conductivity $\left(d \mathrm{Sm}^{-1}\right)$ of seed leachate as influenced by containers $(C)$ and seed treatment chemicals $(T)$ during storage of cluster bean var. Pusa navbahar.

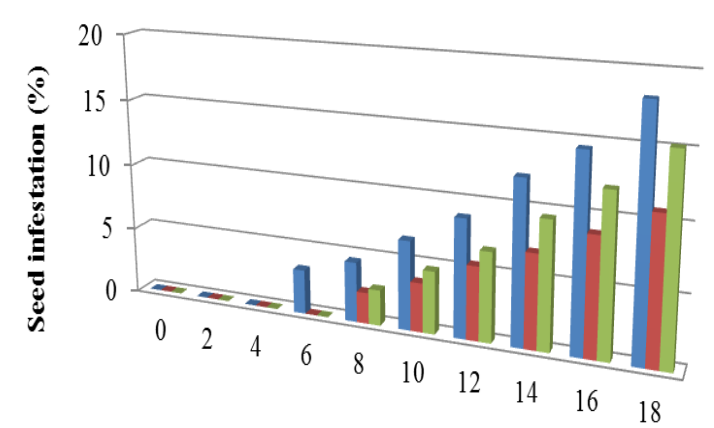

a. Storage period (months)

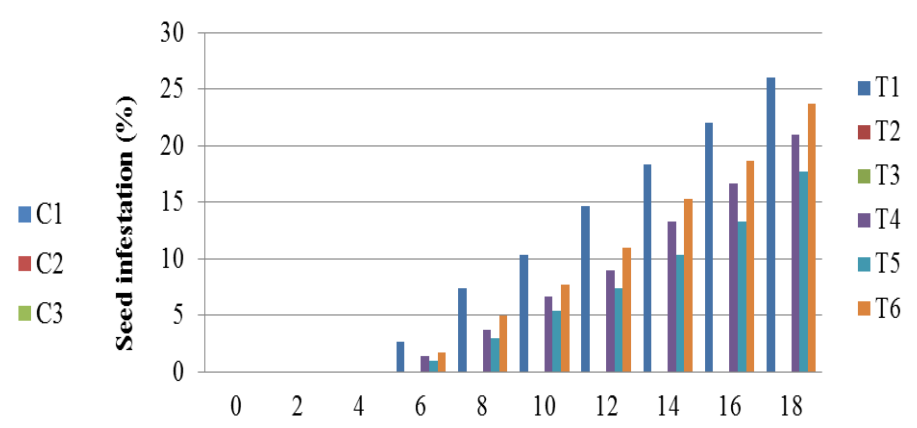

b. Storage period (months)

Fig. 7. Seed infestation (\%) as influenced by containers $(C)$ and seed treatment chemicals $(T)$ during storage of cluster bean var. Pusa navbahar.

Table 2a. Influence of containers $(C)$ and seed treatment chemicals $(T)$ interaction $(C \times T)$ on shoot length $(\mathrm{cm})$ during storage of cluster bean var. Pusa navbahar.

\begin{tabular}{|c|c|c|c|c|c|c|c|c|c|c|}
\hline \multicolumn{11}{|c|}{ Storage period (months) } \\
\hline $\mathbf{C} \times \mathbf{T}$ & Initial & 2 & 4 & 6 & 8 & 10 & 12 & 14 & 16 & 18 \\
\hline $\mathrm{C}_{1} \mathrm{~T}_{1}$ & 16.50 & 16.10 & 15.78 & 15.35 & 14.61 & 13.80 & 12.70 & 11.65 & 10.40 & 9.00 \\
\hline $\mathrm{C}_{1} \mathrm{~T}_{2}$ & 16.45 & 16.43 & 16.15 & 15.85 & 15.35 & 15.00 & 14.15 & 13.90 & 13.08 & 12.48 \\
\hline $\mathrm{C}_{1} \mathrm{~T}_{3}$ & 16.63 & 16.53 & 16.25 & 16.05 & 15.65 & 15.30 & 14.60 & 14.25 & 13.13 & 12.83 \\
\hline $\mathrm{C}_{1} \mathrm{~T}_{4}$ & 16.58 & 16.20 & 16.00 & 15.60 & 14.83 & 14.15 & 13.25 & 12.68 & 11.80 & 11.78 \\
\hline $\mathrm{C}_{1} \mathrm{~T}_{5}$ & 16.63 & 16.35 & 16.13 & 15.70 & 15.10 & 14.80 & 13.88 & 13.70 & 12.90 & 12.15 \\
\hline $\mathrm{C}_{1} \mathrm{~T}_{6}$ & 16.48 & 16.13 & 15.85 & 15.50 & 14.65 & 13.90 & 13.15 & 12.18 & 10.90 & 10.23 \\
\hline $\mathrm{C}_{2} \mathrm{~T}_{1}$ & 16.60 & 16.45 & 16.10 & 15.85 & 15.35 & 15.15 & 13.88 & 13.30 & 12.70 & 12.30 \\
\hline $\mathrm{C}_{2} \mathrm{~T}_{2}$ & 16.63 & 16.53 & 16.25 & 16.10 & 15.73 & 15.40 & 14.70 & 14.15 & 13.80 & 13.30 \\
\hline $\mathrm{C}_{2} \mathrm{~T}_{3}$ & 16.65 & 16.50 & 16.35 & 16.23 & 15.85 & 15.50 & 15.00 & 14.65 & 14.00 & 13.60 \\
\hline $\mathrm{C}_{2} \mathrm{~T}_{4}$ & 16.53 & 16.43 & 16.23 & 16.00 & 15.45 & 15.25 & 13.45 & 13.60 & 13.08 & 12.55 \\
\hline $\mathrm{C}_{2} \mathrm{~T}_{5}$ & 16.60 & 16.50 & 16.23 & 16.00 & 15.50 & 15.30 & 14.05 & 13.88 & 13.50 & 12.80 \\
\hline $\mathrm{C}_{2} \mathrm{~T}_{6}$ & 16.60 & 16.43 & 16.10 & 15.88 & 15.45 & 15.15 & 13.50 & 13.45 & 12.90 & 12.40 \\
\hline $\mathrm{C}_{3} \mathrm{~T}_{1}$ & 16.55 & 16.30 & 15.85 & 15.73 & 15.13 & 14.40 & 13.45 & 12.60 & 11.38 & 10.55 \\
\hline $\mathrm{C}_{3} \mathrm{~T}_{2}$ & 16.60 & 16.50 & 16.28 & 15.85 & 15.65 & 15.15 & 14.50 & 14.00 & 13.50 & 13.05 \\
\hline $\mathrm{C}_{3} \mathrm{~T}_{3}$ & 16.63 & 16.53 & 16.35 & 16.00 & 15.85 & 15.30 & 14.88 & 14.40 & 13.60 & 13.10 \\
\hline $\mathrm{C}_{3} \mathrm{~T}_{4}$ & 16.50 & 16.40 & 16.10 & 15.78 & 15.43 & 14.70 & 13.75 & 13.50 & 12.80 & 11.25 \\
\hline $\mathrm{C}_{3} \mathrm{~T}_{5}$ & 16.55 & 16.43 & 16.18 & 15.75 & 15.58 & 14.85 & 14.00 & 13.75 & 13.18 & 12.70 \\
\hline $\mathrm{C}_{3} \mathrm{~T}_{6}$ & 16.58 & 16.45 & 16.00 & 15.73 & 15.33 & 14.53 & 13.20 & 13.40 & 11.18 & 10.80 \\
\hline $\mathbf{S . E m} \pm$ & - & - & - & 0.055 & 0.050 & 0.053 & 0.046 & 0.062 & 0.140 & 0.076 \\
\hline $\begin{array}{l}\text { CD } \\
5 \%\end{array}$ & NS & NS & NS & 0.156 & 0.141 & 0.150 & 0.130 & 0.177 & 0.397 & 0.215 \\
\hline
\end{tabular}

NS - Non significantContainers $\left(\mathcal{C} ; \mathrm{C}_{1}\right.$ - Cloth bag; $\mathrm{C}_{2}$ - Super grain bag; $\mathrm{C}_{3}$ - Polylined cloth bag; Seed Treatment chemicals (T) $\mathrm{T}_{1}-$ Control $\mathrm{T}_{4}-$ Neem leaf powder(1:20 ratio) $\mathrm{T}_{2}-$ Bavistin $\left(2 \mathrm{~g} \mathrm{~kg}^{-1}\right) \mathrm{T}_{5}$ - Acorus calamus $\left(10 \mathrm{~g} \mathrm{~kg}^{-1}\right) \mathrm{T}_{3}-$ Spinosad $(0.04 \mathrm{ml} / \mathrm{kg}) \mathrm{T}_{6}-$ Cow dung powder $\left(10 \mathrm{~g} \mathrm{~kg}^{-1}\right)$ 
ured from the color region to tip of the primary root with the help of scale. The length between the color region and tip of the primary shoot was considered as shoot length and measured with a centimeter scale. The average root length and shoot length of ten seedlings were computed and expressed in centimeter. The mean seedling dry weight was recorded and expressed in milligrams per 10 seedlings. Seedling vigor index (SVI-I \& II) was calculated by adopting the method suggested by Abdul-Baki and Anderson (1973) and expressed in whole number. The electrical conductivity of seed leachate was determined as per procedure outlined by ISTA (1995) and expressed in $\mathrm{dSm}^{-1}$. The total dehydrogenase activity (TDH) of the seeds was estimated as per the method described by Perl et al. (1978). Based on the existence of insect hole, the number of seeds with insect infestation was counted with 4 $\times 100$ seeds and the mean was reported as insect infestation in percentage by dividing number of seeds infested with total number of seeds taken for counting. The experimental data were statistically analyzed as per the methods outlined by Gomez and Gomez (1984).

\section{RESULTS AND DISCUSSION}

High quality seed is the key to successful agriculture. Modern agriculture demands that each and every seed should readily germinate and produce a vigorous seedling ensuring high yield. Maintenance of seed quality during storage has become most important part of seed production programme, since agriculture is season bound, the storage of seed has become inevitable for farmers, seed producers, breeders and to all those concerned with seed. The loss of seed during storage condition may range from 0 to 100 per cent under unhygienic condition. Seed being a biological material, the loss of seed viability and vigour during storage is a quite natural phenomenon occurring during deterioration process which is inexorable, irreversible and inevitable. Although the complete control of seed deterioration is quite impossible but the rate of degenerative process could be slowed down to a certain extent by providing ideal conditions. On account of the diverse biological activities taking place in seed during storage, the seed deterioration results in impairment of germination and vigour. Seed viability in storage is determined not only by the period of storage, but also the type of container used, initial seed moisture content, storage environment and seed treatments. Therefore, an understanding of how best the seeds can be stored under ambient temperature, relative humidity at relatively low cost, with minimum deterioration in quality for periods extending over one or more seasons will be of immense use to seed industry and farming community. Keeping this in view, an experiment was conducted in order to know the effect of seed treatment chemicals on quality of cluster bean seeds stored in different packaging materials under ambient conditions.

In the present study, the results clearly revealed that the seed quality parameters of cluster bean such as seed moisture content $(\%)$, germination $(\%)$, root length $(\mathrm{cm})$, shoot length $(\mathrm{cm})$, seedling dry weight $(\mathrm{mg})$, seedling vigor index- I and vigor index- II, total dehydrogenase activity, membrane integrity manifested by the electrical conductivity of the seed leachate, seed infestation (\%) status were greatly affected by storage period, packaging materials and seed treatments.

Effect of seed treatments on seed moisture differed significantly from four months of storage, it was significantly lower in seeds treated with spinosad (8.02 to

Table 3. Influence of containers $(\mathrm{C})$ and seed treatment chemicals $(\mathrm{T})$ on total dehydrogenase activity during storage of cluster bean var. Pusa navbahar.

\begin{tabular}{|c|c|c|c|c|c|c|c|c|c|c|}
\hline \multicolumn{11}{|c|}{ Storage period (months) } \\
\hline & Initial & 2 & 4 & 6 & 8 & 10 & 12 & 14 & 16 & 18 \\
\hline \multicolumn{11}{|l|}{ Containers (C) } \\
\hline $\mathrm{C}_{1}$ - Cloth bag & 1.265 & 1.254 & 1.246 & 1.240 & 1.231 & 1.222 & 1.200 & 1.180 & 1.165 & 1.149 \\
\hline $\mathrm{C}_{2}$ - Super grain bag & 1.262 & 1.261 & 1.256 & 1.251 & 1.243 & 1.237 & 1.231 & 1.226 & 1.220 & 1.201 \\
\hline $\mathrm{C}_{3}$ - Polylined cloth bag & 1.262 & 1.259 & 1.252 & 1.247 & 1.235 & 1.228 & 1.203 & 1.213 & 1.203 & 1.176 \\
\hline S.Em \pm & - & - & 0.0003 & 0.0002 & 0.0003 & 0.0002 & 0.0042 & 0.0011 & 0.0002 & 0.0003 \\
\hline $\mathrm{CD}$ at $5 \%$ & NS & NS & 0.0008 & 0.0006 & 0.0007 & 0.0006 & 0.0119 & 0.0030 & 0.0007 & 0.0009 \\
\hline \multicolumn{11}{|l|}{ Seed treatment chemicals $(\mathrm{T})$} \\
\hline $\mathrm{T}_{1}-$ Control & 1.262 & 1.257 & 1.248 & 1.240 & 1.229 & 1.218 & 1.208 & 1.196 & 1.179 & 1.156 \\
\hline $\mathrm{T}_{2}-$ Bavistin $\left(2 \mathrm{~g} \mathrm{~kg}^{-1}\right)$ & 1.264 & 1.260 & 1.254 & 1.250 & 1.242 & 1.236 & 1.221 & 1.215 & 1.206 & 1.187 \\
\hline $\mathrm{T}_{3}-$ Spinosad $(0.04 \mathrm{ml} / \mathrm{kg})$ & 1.264 & 1.258 & 1.256 & 1.253 & 1.247 & 1.242 & 1.232 & 1.220 & 1.214 & 1.197 \\
\hline $\mathrm{T}_{4}-$ Neem leaf powder(1:20 ratio) & 1.262 & 1.257 & 1.250 & 1.244 & 1.234 & 1.226 & 1.214 & 1.201 & 1.191 & 1.169 \\
\hline $\mathrm{T}_{5}-$ Acoruscalamus $\left(10 \mathrm{~g} \mathrm{~kg}^{-1}\right)$ & 1.263 & 1.258 & 1.252 & 1.247 & 1.238 & 1.232 & 1.216 & 1.208 & 1.199 & 1.180 \\
\hline $\mathrm{T}_{6}-$ Cow dung powder $\left(10 \mathrm{~g} \mathrm{~kg}^{-1}\right)$ & 1.262 & 1.258 & 1.248 & 1.242 & 1.231 & 1.220 & 1.177 & 1.197 & 1.186 & 1.162 \\
\hline S.Em \pm & - & - & 0.0004 & 0.0003 & 0.0004 & 0.0003 & 0.0059 & 0.0015 & 0.0003 & 0.0004 \\
\hline $\mathrm{CD}$ at $5 \%$ & NS & NS & 0.0011 & 0.0008 & 0.0010 & 0.0009 & 0.0168 & 0.0043 & 0.0010 & 0.0012 \\
\hline
\end{tabular}

NS - Non significant 
$10.67 \%$ ) closely followed by bavistin (8.03 to 10.88 $\%$ ). Effect of packaging materials on seed moisture differed significantly, it was significantly higher in seeds stored in cloth bag (8.01 to $11.41 \%$ ) compared to super-grain bag (8.01 to $10.66 \%$ ) (Fig.1). Cloth bag being a pervious container, moisture exchange took place frequently until it reached the equilibrium status with environment, thereby this recorded higher moisture at the end of storage period. Super-grain bag which may be attributed to the impervious nature to moisture vapours and thus it has caused less fluctuation in seed moisture content and it eliminates dampness, deterioration, microorganisms and enhance the seed longevity. These findings were in conformity with the findings of Shanthappa Tirakannanavar and Ramaiah (2006) in redgram and Basavegowda et al. (2013) in chickpea who reported the less fluctuation in seed moisture in the impervious packaging materials as compared to cloth bag. Interaction effects of containers and seed treatments were found significant from six months of storage. The seed moisture content for containers and seed treatment interaction was significantly lower in spinosad and bavistin treated seeds stored in super-grain bag and higher was recorded in cloth bag with irrespective seed treatments. The seed moisture content gradually increased with advancement of storage period due to pervious nature of cloth bag.

Significant difference in germination percentage was also noticed between the packaging materials and chemical treatments. Higher germination was observed when seeds were stored in super-grain bag $(72.38 \%)$ due to lower moisture fluctuations. Super-grain bag stored seeds maintained germination above minimum standard for certification i.e. 70 per cent up to 18 months of storage, while the seed packed in cloth bag lost germination beyond 14 months of storage (Table 1 and 1a). Germination was higher in super-grain bag which may be attributed to the ability of the packaging material to prevent the entry of external moisture and the maintenance of moisture content to the original level. The poor performance of seeds stored in cloth bag might be due to the absorption of external moisture, facilitated by its porous nature and subsequent fungal and insect invasion due to rise in moisture content. Seeds treated with spinosad $(77.08 \%)$ have proven better for seed longevity, since they act as a protectant against the growth and development of internal seed borne pests and diseases. Among interaction effect of packaging and chemicals, seeds stored in supergrain bag and treated with spinosad was superior in germination $(80.00 \%)$ over storage compared to other treatment combinations. Similar findings were reported by Kathiravan et al. (2008) in lablab, Shivagouda et al. (2014) in pigeonpea for maintenance seed longevity of treated seeds in impervious containers. Seedling root and shoot length, seedling dry weight, seedling vigour index I, viogur index II and total dehydrogenase activity also differed significantly between the packaging

Table 3a. Influence of containers $(C)$ and seed treatment chemicals $(T)$ interaction $(C \times T)$ on total dehydrogenase activity during storage of cluster bean var. Pusa navbahar.

\begin{tabular}{lllllllllll}
\hline & & \multicolumn{7}{c}{ Storage period (months) } \\
\hline $\mathbf{C} \times \mathbf{T}$ & Initial & $\mathbf{2}$ & $\mathbf{4}$ & $\mathbf{6}$ & $\mathbf{8}$ & $\mathbf{1 0}$ & $\mathbf{1 2}$ & $\mathbf{1 4}$ & $\mathbf{1 6}$ & $\mathbf{1 8}$ \\
\hline $\mathrm{C}_{1} \mathrm{~T}_{1}$ & 1.260 & 1.256 & 1.245 & 1.236 & 1.221 & 1.205 & 1.193 & 1.173 & 1.151 & 1.125 \\
$\mathrm{C}_{1} \mathrm{~T}_{2}$ & 1.267 & 1.257 & 1.248 & 1.244 & 1.237 & 1.233 & 1.198 & 1.187 & 1.174 & 1.165 \\
$\mathrm{C}_{1} \mathrm{~T}_{3}$ & 1.265 & 1.251 & 1.249 & 1.246 & 1.243 & 1.238 & 1.221 & 1.191 & 1.182 & 1.171 \\
$\mathrm{C}_{1} \mathrm{~T}_{4}$ & 1.267 & 1.252 & 1.246 & 1.239 & 1.229 & 1.219 & 1.197 & 1.175 & 1.161 & 1.142 \\
$\mathrm{C}_{1} \mathrm{~T}_{5}$ & 1.265 & 1.254 & 1.248 & 1.241 & 1.234 & 1.224 & 1.196 & 1.181 & 1.169 & 1.158 \\
$\mathrm{C}_{1} \mathrm{~T}_{6}$ & 1.264 & 1.253 & 1.242 & 1.237 & 1.225 & 1.211 & 1.195 & 1.171 & 1.155 & 1.131 \\
$\mathrm{C}_{2} \mathrm{~T}_{1}$ & 1.264 & 1.259 & 1.251 & 1.245 & 1.238 & 1.232 & 1.224 & 1.219 & 1.205 & 1.184 \\
$\mathrm{C}_{2} \mathrm{~T}_{2}$ & 1.260 & 1.262 & 1.260 & 1.256 & 1.247 & 1.241 & 1.237 & 1.231 & 1.228 & 1.211 \\
$\mathrm{C}_{2} \mathrm{~T}_{3}$ & 1.264 & 1.262 & 1.263 & 1.259 & 1.250 & 1.247 & 1.240 & 1.239 & 1.231 & 1.224 \\
$\mathrm{C}_{2} \mathrm{~T}_{4}$ & 1.260 & 1.261 & 1.254 & 1.248 & 1.241 & 1.235 & 1.229 & 1.223 & 1.218 & 1.194 \\
$\mathrm{C}_{2} \mathrm{~T}_{5}$ & 1.260 & 1.262 & 1.257 & 1.252 & 1.244 & 1.238 & 1.231 & 1.227 & 1.225 & 1.204 \\
$\mathrm{C}_{2} \mathrm{~T}_{6}$ & 1.263 & 1.261 & 1.252 & 1.247 & 1.239 & 1.231 & 1.226 & 1.221 & 1.215 & 1.191 \\
$\mathrm{C}_{3} \mathrm{~T}_{1}$ & 1.260 & 1.257 & 1.249 & 1.240 & 1.228 & 1.217 & 1.209 & 1.197 & 1.182 & 1.160 \\
$\mathrm{C}_{3} \mathrm{~T}_{2}$ & 1.266 & 1.260 & 1.254 & 1.250 & 1.241 & 1.234 & 1.229 & 1.228 & 1.218 & 1.184 \\
$\mathrm{C}_{3} \mathrm{~T}_{3}$ & 1.264 & 1.260 & 1.257 & 1.255 & 1.248 & 1.241 & 1.234 & 1.231 & 1.228 & 1.198 \\
$\mathrm{C}_{3} \mathrm{~T}_{4}$ & 1.260 & 1.259 & 1.250 & 1.244 & 1.231 & 1.224 & 1.217 & 1.206 & 1.195 & 1.172 \\
$\mathrm{C}_{3} \mathrm{~T}_{5}$ & 1.264 & 1.259 & 1.252 & 1.247 & 1.236 & 1.234 & 1.221 & 1.216 & 1.204 & 1.179 \\
$\mathrm{C}_{3} \mathrm{~T}_{6}$ & 1.260 & 1.259 & 1.249 & 1.242 & 1.229 & 1.218 & 1.111 & 1.199 & 1.188 & 1.164 \\
$\mathbf{S . E m} \pm$ & - & - & 0.0007 & 0.0005 & 0.0006 & 0.0005 & 0.0103 & 0.0026 & 0.0006 & 0.0008 \\
$\mathbf{C D}_{\mathbf{D}}$ at 5\% & $\mathbf{N S}$ & $\mathbf{N S}$ & 0.0020 & 0.0015 & 0.0018 & 0.0015 & 0.0291 & 0.0074 & 0.0017 & 0.0021 \\
\hline
\end{tabular}

NS - Non significantContainers $\left(\mathrm{C} ; \mathrm{C}_{1}-\right.$ Cloth bag; $\mathrm{C}_{2}$ - Super grain bag; $\mathrm{C}_{3}$ - Polylined cloth bag; Seed Treatment chemicals (T) $\mathrm{T}_{1}$ - Control $\mathrm{T}_{4}-$ Neem leaf powder(1:20 ratio) $\mathrm{T}_{2}$ - Bavistin $\left(2 \mathrm{~g} \mathrm{~kg}^{-1}\right) \mathrm{T}_{5}-$ Acorus calamus $\left(10 \mathrm{~g} \mathrm{~kg}^{-1}\right) \mathrm{T}_{3}-$ Spinosad $(0.04 \mathrm{ml} / \mathrm{kg}) \mathrm{T}_{6}-$ Cow dung powder $\left(10 \mathrm{~g} \mathrm{~kg}^{-1}\right)$ 
materials at the end of the storage period. Higher root length $(10.98 \mathrm{~cm})$, shoot length $(12.83 \mathrm{~cm})$ seedling dry weight (126 mg), seedling vigour index I (1726), seedling vigour index II (9171) and TDH activity (1.201) were observed in super-grain bag seeds compared to cloth bag in which the root length $(9.50 \mathrm{~cm})$, shoot length $(11.41 \mathrm{~cm})$ seedling dry weight $(119 \mathrm{mg})$, seedling vigour index I (1309), seedling vigour index II (7475) and total dehydrogenase activity (1.149) were lower. Further, the seeds treated with spinosad recorded higher quality parameters like root length $(11.10 \mathrm{~cm})$, shoot length $(13.18 \mathrm{~cm})$, mean seedling dry weight $(150 \mathrm{mg})$, seedling vigour index I (1873), seedling vigour index II (11586) and TDH activity (1.197) compared to untreated control (Fig. 2, 3, 4, 5 and Table 2, 2a, 3 and $3 \mathrm{a}$ ).

Interactions of packaging and chemicals were also differed significantly for various seed quality attributes over storage. The root length $(11.70 \mathrm{~cm})$, shoot length $(13.60 \mathrm{~cm})$, seedling dry weight $(152 \mathrm{mg})$, seedling vigour index I (2024), seedling vigour index II (12140) and TDH activity (1.224) were higher in seeds treated with spinosad and stored in super-grain bag compared to other treatment combinations. Similar findings wherein seed treatment and storage containers had significant role in preserving the seed viability and quality were also observed by Tammanagowda (2002) in greengram, Pramila (2003) in blackgram, Adebisi et al. (2007) in okra, Thirusenduraselvi and Jerlin, (2007) in bitter gourd, Mahesh Babu and Ravi Hunje (2008) in soybean, Monira et al. (2012) in soybean, Basavegowda et al. (2013) in chickpea, Shivagouda et al. (2014) in pigeonpea.

Electrical conductivity showed significant differences between the containers from four months to eighteen months of storage. Electrical conductivity of seed leachate is negatively correlated with seed quality. Higher conductivity was recorded in cloth bag $(0.408$ $\left.\mathrm{dSm}^{-1}\right)$ compared to super-grain bag $\left(0.377 \mathrm{dSm}^{-1}\right)$ (Fig. 6). Electrical conductivity of the leachate rapidly increased in the seeds stored in cloth bags, whereas it increased slowly in seeds packed in super-grain bag and polylined cloth bags. Thus, the loss of membrane integrity, which is one of the early symptoms of seed ageing, was faster in seeds packed in moisture pervious containers i.e. cloth bags. As evidenced by the comparative loss of germination and vigour, a similar pattern was observed with respect to electrolyte leakage. Increase in EC may be attributed to permeability of the seed membrane as seed ages, many substances such as sugars, free amino acids, organic acids etc., will leach out in the presence of water, disruption of membrane integrity, increase in free fatty acid level and free radical production by lipid peroxidation leads to leakage of electrolytes due to ageing of seed. Similar findings were obtained by Kumar Kant Singh and Malavika Dadlani (2003) in soybean who reported highly significant negative correlation between EC value of seed leachate and viability. The present study revealed a close association between the enhanced solute leakage and disintegration of membrane integrity leading to the loss of seed viability and vigour which can be significantly controlled by proper packaging.

In the present investigation, electrical conductivity (EC) of seed leachate was increased progressively with the increase in storage period in all the seed treatments. Among chemicals, spinosad has recorded lower EC $\left(0.373 \mathrm{dSm}^{-1}\right)$ compared to control $\left(0.401 \mathrm{dSm}^{-1}\right)$ (Fig. 6). This variation in electrical conductivity of seed leachate indicate increased membrane permeability and decrease in integrity of seed coat and cellular membrane deterioration. Degradation of cellular membrane integrity might have increased the EC of seed leachate value but spinosad treatment gave protection against the mycoflora and bruchid infestation and might have reduced the deterioration of seed during storage. Loss of membrane integrity during storage would be the main reason for increased electrical conductivity and also evidenced by structural change and changes in membrane composition (Delouche and Baskin, 1973). These results are in conformity with findings of Shobha et al. (2006) in soybean, Kathiravan et al. (2008) in lablab, Mahesh Babu and Ravi Hunje (2008) in soybean. Electrical conductivity was significant between the containers and seed treatments from six months to eighteen months of storage. Among the interactions, the electrical conductivity of seed leachate was significantly lower in seeds treated with spinosad and packed in super-grain bag $(0.368$ $\mathrm{dSm}^{-1}$ ) compared to all other combinations. A steep increase in electrical conductivity values from 0.275 to $0.308 \mathrm{dSm}^{-1}$ was observed with untreated seeds stored in cloth bag at the fourth month of storage, which had further increased to $0.425 \mathrm{dSm}^{-1}$ on the $18^{\text {th }}$ month of storage.

The EC values recorded for treated seeds were significantly lower than those of the untreated seeds. The higher EC values obtained with leachates from untreated seed samples from cloth were associated with low viability and reduced seedling vigour. The weaker the membrane system, the larger would be the quantity of electrolytes leached from the seeds and greater the conductivity of steep water. This was presumably due to lack of membrane integrity in those seeds resulting in the enhanced leaching of electrolytes. The seeds treated with spinosad, recorded lesser EC values throughout storage period owing to their involvement in prevention of deterioration of seeds or maintaining cell membrane integrity. Many workers reported negative correlation between EC and seed quality [Kathiravan et al. (2008) in lablab, Tejashwi et al. (2014) in marigold].

Seed infestation (\%) also differed significantly be- 
tween the packaging materials and chemicals over 18 months of storage. However, there was no infestation of bruchid up to four months of storage period. Thereafter, infestation increased gradually as the storage period progressed. Seeds treated with spinosad $(0.04$ $\mathrm{ml} / \mathrm{kg}$ ) and bavistin $\left(2 \mathrm{~g} \mathrm{~kg}^{-1}\right)$ recorded zero seed infestation at the end of storage period. The untreated seeds recorded significantly higher $(26.00 \%)$ infestation after eighteen months of storage (Fig. 7). There was no insect infestation in seeds which were packed in supergrain bag up to six months. Seeds stored in cloth bag recorded higher infestation (18.17\%). However, polylined cloth bag stored seeds recorded lower infestation $(15.17 \%)$ (Fig. 7). The fluctuations in moisture content of seeds stored in cloth bag may also contribute for higher infestation. Insects are generally active when the seed moisture content is above 8-9 per cent (Harrington and Douglas, 1970). The seed moisture content of seeds in cloth bag had increased beyond the initial level of 8 per cent and this increase had favoured the multiplication of the bruchids, as was evident from higher infestation in the untreated seeds at the end of storage. Consequently, the viability and vigour of these seeds were considerably reduced within few months. In the present study, higher seed quality parameters with lower percentage of seed infestation was noticed in super-grain bag which may be attributed to the impervious nature to moisture vapours and thus it has caused less fluctuation in seed moisture content and seed infestation. Interaction effect of containers and seed treatment was found significant for seed infestation during storage period. With advancement of storage period, there was increase in per cent insect infestation in all the seed treatments except spinosad and bavistin. At the initial two and four months of storage period, insect infestation was not observed. At the end of storage period, higher infestation was recorded in untreated seeds stored in cloth bag (31\%). However, spinosad, bavistin treated seeds stored in super-grain bag, poly-lined cloth bag recorded zero infestation at the end of storage period. The treatment with spinosad significantly lowered larval and adult population of bruchid beetles due their ovicidal and inhibitory repellent properties. The similar results with chemical (insecticidal) treatment of seeds were reported by Srimathi et al. (2003) in cowpea, Ghelani et al. (2009) in pearl millet.

\section{Conclusion}

Seed quality attributes of cluster bean was significantly influenced by packing materials and seed treatments during storage. The seeds stored in cloth bag showed poor quality parameter i.e. decreased germination (62 $\%$ ), vigour (1309) and higher EC value (0.408) due to increased seed quantitative losses and it might be ascribed to the increased activities of pulse bruchids due to greater fluctuations in moisture content in view per- meable nature of cloth bag to moisture vapours. Seeds stored in super grain bag recorded higher germination $(72.38 \%)$ and other quality attributes, irrespective of seed treatments and they were almost free from insect (bruchid) damage throughout the storage. Further, seed treatment with spinosad @ $0.04 \mathrm{ml} / \mathrm{kg}$ maintained higher seed quality attributes like germination (77.08\%), seedling vigour index (1873), dehydrogenase activity (1.197) etc., but the untreated seeds recorded significantly lower germination $(62.25 \%)$ and other quality attributes at the end of eighteen months of storage. Therefore, from the study it is concluded that seeds of cluster bean treated with spinosad @ $0.04 \mathrm{ml} / \mathrm{kg}$ and packed in super-grain bag could be stored for longer period of 18 months under ambient conditions of Bengaluru without drastic reduction in seed quality.

\section{REFERENCES}

Abdul-Baki, A. A. and Anderson, J. D. (1973). Vigour determination in soybean by multiple criteria. Crop Sci., 13: 630-633.

Abdul-Baki, A. A. and Anderson, J. D. (1973a). Physiological and biochemical deterioration of seed. In Seed Biology (II Ed): Kozlowski, T. T., Academic Press, New York, London Pp.283-315.

Adebisi, M. A., Akintobi, D.C.A. and Oyekale, K. O. (2007). Preservation of okra seed vigour by seed treatments and storage containers. Nigerian J. Hort. Sci., 12: 1-7.

Anonymous. (1996). International Rules for Seed Testing. Seed Sci. \& Technol., 24: 1-255.

Anonymous. (2015). Weather report. AICRP on Agrometerology, University of Agricultural Sciences, GKVK, Bengaluru.

Aykroyd, U. R. (1963). Indian Council of Medical Research, Special Report, Series, No. 42, Vegetables, National Book Trust India (4 ${ }^{\text {th }}$ Edn.), New Delhi Pp. 188-191.

Basavegowda, Gururaj Sunkad and Arunkumar Hosamani (2013). Effect of commercial cold storage conditions and packaging materials on seed quality of chickpea (Cicer Arietinum L.). Global J.Sci. Frontier Res., 13 (2): 22-28.

Delouche, J. C. and Baskin, C. C. (1973). Accelerated ageing techniques for predicting the relative storability of seed lots. Seed Sci. \& Technology, 1: $427-452$.

Doijode, S. D. (1988). Effect of storage environment on brinjal (Sorghum melongena) seed viability. Progressive Horticulture, 20: 292-293.

Ghelani, Y. H., Dhedhi, K. K., Joshi, H. J., Raghvani, K. L. and Dangaria, C. J. (2009). Effect of insecticidal seed treatment on viability of pearl millet seed during storage. Karnataka J. Agric. Sci., 22 (3): 633-634

Gomez, K.A. and Gomez, A.A. (1984). Statistical procedures for agricultural research. John Wiley and sons, Inc. London, UK ( $2^{\text {nd }}$ edtn) $13-175$

Harrington, J. F. and Douglas, J. E. (1970). Seed storage and packaging applications for India. National Seeds Corporation Ltd., New Delhi.

ISTA. 1995. Recommended seed vigour tests. Hand Book of Vigour Test Methods, Pp 22-30

Kapoor, R, Arya A, Siddiqui, M. A, Amir, A. and Kumar, H. (2010). Seed deterioration in chickpea (Cicer arietinum 
L.) under accelerated ageing. Asian J Plant Sci., 9(3) 158-162

Kapoor, N, Arya, A, Siddiqui, M. A, Kumar, H. and Amir, A. (2011), Physiology and biochemical changes during seed deterioration in aged seeds of rice (Oryza sativa L.). American J. of Plant Physiology, 6(1): 28-35

Kathiravan, M., Vijayakumar, A. and Vanitha, C. (2008). Effect of dry dressing treatments and containers on seed quality parameters in lablab (Lablab purpureous L.) under natural ageing conditions. Indian J. Agric. Res., 42(1): $62-66$

Kumar Kant Singh and Malavika Dadlani. (2003). Effect of packaging on vigour and viability of soybean seeds during ambient storage. Seed Res.,31(1): 27-32

Mahesh Babu, H. M. and Ravi Hunje. (2008). Effect of seed treatment with botanicals on storability of soybean. Karnataka J. Agric. Sci., 21(3): 357-360

Monira, U. S., Amin, M. H. A., Marin, M. and Mamun, M. A. A.(2012). Effect of containers on seed quality of storage soybean seed. Bangladesh Res. Pub. J., 7(4): 421-427

NRAA. (2014) Potential of rainfed guar (cluster beans) cultivation, Processing and Export in India. Policy paper No.3 National Rainfed Area Authority, NASC Complex.DPS Marg, New Delhi-110012, India: 109p.

Perl, M., Luria, I. and Gelmond, H. (1978). Biochemical changes in sorghum seeds affected by accelerated ageing. J. Exptl. Bot., 29: 497-509

Pramila R Gangal (2003). Influence of pre harvest insecticidal spray on seed yield and quality and post harvest seed treatment on storability of black gram (Vigna mungo). M. Sc. (Agri.) Thesis, Univ. Agric. Sci., Dharwad,
Karnataka (India)

Shanthappa Tirakannanavar and Ramaiah, H. (2006). Effect of seed treatment and containers on storability of red gram seeds. Abstracts, XII National seminar on prosperity through quality seed, pp 139

Shelar V. R, Shaikh R. S and Nikam A. S. (2008). Soybean seed quality during storage: A review. Agric. Rev., 29 (2) $125-131$

Shivagouda Patil., Rajendra Prasad, S., Bharamaraj Badiger. Yegappa Hipparagi., Maruthi, $\mathrm{K}$ and Shankrayya. (2014). Impact of seed treatment chemicals on seed storability in pigeonpea (Cajanus cajan (L.) Millsp.). The Bioscan., 9(3): 985-989

Shobha, B. N., Ramegowda, Devaraju, P. J. and Prasanna, K. P. R. (2006). Influence of seed colouring on seed quality during storage in soyabean. Abst. National Seed Seminar on Prosperity through Quality Seed, pp126.

Srimathi, P.G., Sasthri, E. P., Venkatachalam, R., Geetha and Malarkodi, K. (2003). Influence of pre-storage treatments on storability of vegetable cowpea. Legume Res., 26 (3): 166-171

Tammanagowda, P. (2002). Influence of organics on seed yield, quality and storability studies on green gram cv. Chinamung. M.Sc. (Agri.) Thesis, Univ. of Agric. Sci., Dharwad.

Tejashwi P. Kumar., Asha, A.M., Maruthi, J.B.and Vishwanath, K. (2014). Influence of seed treatment chemicals and containers on seed quality of marigold during storage. The Bioscan., 9(3): 937-942

Thirusenduraselvi, D. and Jerlin, R. (2007). Enhancing the storability of bitter gourd $\mathrm{cv}$. CO 1 by pelleting treatments. Madras Agric. J., 94(7-12): 192-204 